\title{
STILL PLAUSIBLE AND INTELLIGIBLE? TOWARDS A HERMENEUTIC OF CONGRUENT BIBLICAL THEOLOGY FOR TODAY
}

\author{
J.M. Vorster \\ Faculty of Theology \\ North-West University
}

\section{Abstract}

This article focusses on the question of whether a hermeneutic of congruent biblical theology, founded in the classic reformed tradition, can still be regarded as plausible and intelligible for doing theology and applying Christian ethics today. The central theoretical argument of the discussion is that a hermeneutic of congruent biblical theology in the abovementioned sense can still be plausible and intelligible under specific conditions. First and foremost: Scripture should be seen as the written revelation (Word) of God, inspired by the Spirit of God, and as more than just an ancient text. This inspiration can be termed "organic inspiration" because the Spirit inspired and used humans, within their cultural and socio-historical contexts, their spiritual experiences, languages and expectations to write the texts. Approaching Scripture from this premise, interpreters should for understanding the text, read the text using the modern tools of lexicography and deal thoroughly with the cultural and socio-historical contexts of the ancient authors and the implications thereof. In this process, interpreters must be aware of the fact that they approach Scripture with various forms of pre-understanding and should deal with these by way of the tools of the hermeneutical circle. Passages in Scripture must be analysed and interpreted in light of the wholeness of Scripture and its congruent biblical theology. Furthermore, a "hermeneutic of congruent biblical theology" can add value to biblical studies and new theological knowledge by considering findings in modern literary theories as long as these do not disregard the belief that Scripture is the inspired authoritative written Word of God. Lastly, a hermeneutic of congruent biblical theology must function within the ambit of the Reformed dictum of "semper reformanda" - the quest for continuous revisiting and reevaluation of the findings of biblical interpretation in the course of history.

Keywords: Hermeneutics; Revelation; Congruent theology; Hermeneutical circle; Pre-understanding; Inspiration of Scripture; Organic inspiration; Semper reformanda.

\section{Introduction}

The principles of biblical interpretation as they were developed in the classical Reformed tradition are, since the emergence of the science of theological hermeneutics, under serious review. The late nineteenth-century schools of historical criticism (see Barton 1998:9), literary criticism (see Jasper 1998:21) and form criticism (see Bultmann 1967) 
were the first to question the positivist approach to the interpretation of the biblical text in the history of Christian theology (see Van der Walt 1962; Berkouwer and Van der Woude 1969). These were followed by challenges posed to biblical hermeneutics by the radical liberal theology of secularism and the death of God proposed by Vahanian (1961), Cox (1965), Altizer (1966), and Hamilton (1966) and the contextualism of liberation theologies (Fierro 1977). Contemporary hermeneutical theories, inspired by theorists such as Gadamer (1975), Ricoeur (1981a; 1981b) and Derrida (1997; 2004), make a case for the ambiguousness of any notion of objectivity in the pursuance of truth either by claiming the existence of an "objective truth" or the neutrality of either the ancient author or the modern reader. Some of the new literary theories propose a deconstruction of the text on the grounds that the text does not mean what it appears to mean and nothing ultimately means what it first seems to say. When reading the biblical text as an ancient text, the reader must be aware of the fact that the biblical text is an interpretation of an interpretation and must therefore approach it with a sense of suspicion (hermeneutics of suspicion) ${ }^{1}$. These hermeneutical theories inspired biblical scientists to apply various new literary theories to the interpretation of the biblical text and to question traditional doctrines about the notion of "biblical truth" and the divine authority and inspiration of Scripture.

Tracy (1994:302) is correct when he says that "The influence of literary criticism and literary theory on Christian theologies has become a major factor in any reasonable interpretation or assessment of theology today". Furthermore, these developments in hermeneutical theories in modern theology cast a shadow over the principles of biblical interpretation as they were entertained in the classic Reformed tradition with its emphasis on the idea of God's revelation in Scripture. The Reformation's hermeneutic can be termed "hermeneutic of congruent biblical theology", although many theologians in the Reformed tradition have set aside classic Reformed principles and endeavoured to design new theories on how the ancient biblical text should function in the current post-secular and post-modern paradigm. In view of modern hermeneutical theories, the hermeneutic of congruent biblical theology is suspected of entertaining a "naïve realistic"2 approach

1 The concept "hermeneutics of suspicion" is attributed to the philosophy of Ricoeur. Thiselton (2009:228-254) explains and argues the hermeneutics of Ricoeur in a constructive way, with references to other exponents and critics of Ricoeur's plea for suspicion of the speech of the ancient biblical author, which is a speech of another behind the author.

2 In his thorough research of the influence of Calvinism and neo-Calvinism on the development of Christian nationalism and "Apartheid theology" in South Africa, Deist (1994:155ff) employs the concept "naïve realism" to refer to an approach to Scripture where the naïve acceptance of Scripture as the Word of God, as an objective truth and above any form of rational scepticism, is seen as essential for the development of Calvinism as a life and worldview. Naïve realism should, in his view, be a distortion of Reformed faith and as the direct reason for "Apartheid-theology". 
to Scripture and of being "fundamentalist" 3 and "biblicist"4 and is regarded by many as no longer plausible and intelligible for doing responsible theology.

This article focusses on the question of whether a hermeneutic of congruent biblical theology, modelled on the basic trajectories of classic reformed tradition, can still be regarded as plausible and intelligible for doing theology and applying Christian ethics today. The central theoretical argument of the discussion is that a hermeneutic of congruent biblical theology is still plausible and intelligible under specific conditions. My argument rests on the confessional premise that theology is not possible if we discard the notion of God's self-revelation through Scripture. The structure of the article will unfold as follows: The first section, explains the knowledge of God and the role of the written word in the Reformed tradition. The second section, argues that the hermeneutical principles flow from the knowledge of God and affirm a hermeneutic of congruent biblical theology, and the last section, will postulate the findings and offer an answer to the research question above.

\section{The knowledge of God}

The classic Reformed creeds commence with a confession that God exists. They resonate the three ecumenical creeds of early Christianity, which bear witness of belief in the existence of the triune God. The existence of God cannot be proved by way of philosophical reasoning, as in the Aristotelian view of the "initial mover" or the modern concept of "intelligent design". The existence of God is a matter of belief, and Christian faith stems from this axiom. Modernism, with its high regard for a positivist approach to scientific research, rejected the validity of any axiomatic foundations for epistemology. This idea is still present at many universities which regard theology as below reason and pseudo-science, with no place in academic scholarship. ${ }^{5}$ However, the authority of reason and the notion that theology is below reason are gradually becoming less accepted in current academic research. This development is due to the influence of Kuhn's account of paradigms in doing science and the devaluation of the dominance of reason in science and "scientific methods" by post-modernism (see Kuhn 1970; Foucault 1970; Lyotard 1991). This development reinvigorates the plausibility of axiomatic angles of approach in scientific research when they are scientifically agreed upon in a ruling paradigm. The post-modern (post-positivist) view of science thus provides space for doing theology on

The term fundamentalism emerged in the US in 1920 as a description of conservative Christians who adhered to the "fundamentals" in the face of liberal theology. These fundamentals were, among others, the inspiration and verbal inerrancy of Scripture and a strictly literal interpretation of the ancient text (Marsden 1991:9). In his study of fundamentalism, Marsden (1991:57) indicates that, since 1930 in the US, the term was increasingly used to describe several groups of American Protestants who were willing to wage ecclesiastical war against modernism in theology and the cultural changes that modernists celebrated. See also the description of Barr (2001:363).

4 The term "biblicism" is commonly used to denote a particular way of dealing with the Bible, especially the expectation that it can be transposed directly into modern reasoning and lifestyles (Ritschl 1999:255). Douma (1996:363) employs the term to "that appeal to Scripture which uses the biblical texts in an atomistic (isolated) way by lifting them out of their immediate contexts or out of the whole context of Scripture."

5 Welker (1994:40ff) argues, with valid arguments, that theology today is still influenced by old forms of thought that inhibit the translation of biblical ideas in society today. These outdated forms stem from the modernist paradigm where reason, objectivity, and neutrality guided science and devalued faith and religion. Theology today should in his view be liberated from these old forms of thought in order to become a vibrant and inspiring force in human life today (for an illuminating explanation of his critique on the old forms of thought, see Van der Westhuizen (2017b). 
the foundation of the Reformed creeds' axiom about the existence of God. The academic use of this axiom is thus plausible.

Calvin (Inst. I:2:1:7) founded his theology on the conviction that God exists and that humans can know God. The perfect knowledge of God was a creational gift, implanted in the human mind, but was distorted and corrupted by sin. However, every human being still "has a seed of religion, divinely sown in all" (Calvin Inst. I:4:1:12). This seed of religion brings about the light of reason and a moral sense in every human being (lex naturalis) that is sufficient to prevent humankind and society from falling into total chaos (Calvin II:2:13:166). ${ }^{6}$ But the light of reason and the seed of religion are not enough to reconcile humankind with God. Reconciliation can only occur by way of atonement founded in Christ. As an act of free grace, God reveals this knowledge in Scripture. Scripture is God's special revelation. The Reformed creeds ${ }^{7}$ utilized Calvin's idea of the duplex cognito Dei, that is God's general revelation in the "book of nature" and his particular revelation in "the written word" (Scripture). The Belgic Confession testifies in Article 2:

We know Him by two means: first, by creation, preservation, and government of the universe; (Ps. 19:2; Eph.4:6) which is before our eyes as a most elegant book, wherein all creatures, great and small, are as so many characters leading us to contemplate the invisible things of God, namely, his internal power and divinity, as the apostle Paul sayeth (Rom. 1:20). All things which are sufficient to convince men and to leave them without excuse. Secondly, He makes Himself more clearly and more fully known to us by his holy and divine Word (Ps. 19:8; 1 Cor. 12:6), that is to say, as far as it is necessary for us to know in this life, to his glory and our salvation." (see also Heid. Cat. Q/A 122; Canons of Dort, Head III and IV, arts. 6 and 7; Westminster Confession of Faith, I:1 and the Westminster Larger Catechism Q/A 2 and the references to Scripture in these statements.)

The creeds then proceed with an explanation of the history, character, purpose and inspiration of the "written word" (Scripture).

\section{God's revelation in Scripture}

The creeds concur that Scripture was inspired by the Spirit of God and written by humans. God has spoken through the prophets and apostles in ancient times and still speaks to us today through the Holy Scriptures (Belgic Confession: art 3; Second Helvetic Confession I:1). God inspired people within ancient cultural and social contexts

Barth, in his debate with Brunner, questioned the viewpoint that Calvin accredited any theological significance to the idea of natural law (Brunner and Barth 1946). Modern research on the theological meaning of natural law in Reformed theology indicates that Barth misinterprets Calvin in this regard, possibly due to his fierce resistance against the natural theology of German Christians of his time. Calvin indeed entertained the idea of natural law, which enables all humans to be reasonable and moral and to have a longing for God (see Grabill 2006:70; Witte 2007:59; VanDrunen 2010; 2014:41)

7 The direct quotations from the Reformed creeds, namely the Belgic Confession (1561), the Heidelberg Catechism (1563), the Second Helvetic Confession (1566), the Canons of Dort (1619), The Westminster Confession of Faith (1647), the Westminster Shorter Catechism (1647) and the Westminster Larger Catechism (1648) are taken from the publication of a synopsis of the original texts of these documents by Beeke and Ferguson (1999). 
to write down his revelation in their own styles and languages with the purpose of speaking to the people of God in a certain time and context about the creation and recreation of his reign (kingdom) and its relevance for humankind. Scripture, containing the sixty-six canonical books, is an ancient text in the sense that people wrote the texts in a certain time and place, but it is more than any other ancient text because it was inspired by the Spirit of God (theopneustie).

Word and Spirit are inextricably linked in Reformed Theology. The Word of God can never be detached from the Spirit of God. The Word alone is unable to correspond to the riches and the mysteries of God. It is the Spirit which first enables people to speak from, and to God. Without the Spirit, human beings do not get the power of faith and the language of faith. The word without the Spirit is weak and becomes fossilised, leaving humans with uncertainty. Without the Spirit, the word is an outdated book or, in the words of Barth (1978:525), a "paper pope". Only by and through the Spirit does the Word become powerful enough to overcome the uncertainty, according to Welker's (1996:77) defence of the close connection of Word and Spirit and his proposition of a realistic theology of the Spirit for the contemporary world.

The idea of the divine inspiration of the biblical text has been thoroughly researched in Reformed theology since the late nineteenth century in reaction to the rationalism and Positivism of the Enlightenment and the emergence of classical theological liberalism. The Dutch systematic theologian Bavinck (1928:357) explained, in that era, that the biblical text itself claims divine inspiration, and he constructs his argument on various biblical material in both the Old and the New Testament. He claims that the doctrine of the divine inspiration of Scripture is the oldest and most widely accepted doctrine in the Christian tradition. Welker (1994:276) contends that, without the divine inspiration, Scripture would be only a library of human wisdom and ideas. The acceptance of the divine inspiration of Scripture determines its interpretation. However, ideas about the character of this inspiration moved into various patterns of reasoning (Kärkkäinen 2019:17). Very influential was the dictation theory of Orthodox Reformed theology that defended the idea of "verbal inspiration", which entails that not only the general intent of Scripture, but the words of the biblical authors were thought to be directly inspired and dictated by God's Spirit. This theory was also labelled as a view of "mechanical inspiration", as if the biblical authors were no more than automations, instruments of the Spirit without any contextual influences from their environment (Van der Kooi and Van den Brink 2017:538). The idea of "verbal inspiration" became highly influential in the development of Evangelicalism and Pentecostalism in the twentieth century as well as in neo-Calvinism in the Netherlands and South Africa; this resulted in questionable ecclesiastical customs and moral stances due to the use of mere "proof texts" (loca probantia). The South African biblical scientist, Deist (1994:322) typified this approach as "naïve realism", which was in his view responsible for the biblical justification of the political structure of Apartheid in South Africa. Over and against this theory in Orthodox Reformed theology, Bavinck (1929:402) made a case for the theory of "organic inspiration", which means that God is the auctor primarius, who inspired the authors as the auctors secundarii and used their contexts, reasoning, emotional conditions, styles and personalities to write down God's revelation. Recently, Kärkkäinen (2019:18) defended this theory by speaking of "divine-human synergy", an outlook: "...where the humanity of the biblical writers is not set aside, but confirmed" (Kärkkäinen 2019:18). 
The authors were children of their time and their writings bear the stamp of their time (Peels 1996:53). The angle of approach in this research is the view of "organic inspiration" as the theory is argued by Bavinck and held by the above-mentioned expositors.

Closely related to the doctrine of the divine inspiration of Scripture is the confession of the self-convincing authority of Scripture (Autopistia) due to the testimony of the Spirit (Belgic Confession, art. 5; Second Helvetic Confession II; Westminster Confession of Faith I, 4-6; Canons of Dort III and IV, 13-14). This pre-modern idea was criticised in the age of modernism with its positivist view of science, which claims that science cannot depend on unchanging and self-convincing truths. However, the recent research of the Dutch theologian, Van der Belt (2006:324) about the concept autopistia indicates that the contemporary post-modern paradigm is more open to such an idea, because the validity of an idea depends on the scientific agreement in a ruling paradigm and not on the notion of "objective" rational proof as modernism claimed. Postmodernism rejects the idea of authoritative, objective principia of science. Van der Belt (2006:324) therefore argues that:

The idea that we do not believe the Scriptures on account of the church or of logical demonstration by professional theologians, but because we are personally convinced by the text of Scripture itself, fastens upon the feeling that truth is something personal and that the only reason to believe the Scriptures lies in the personal conviction that they are true.

The concept autopistia, as it is confessed in Reformed theology, can thus also be regarded today as a plausible angle of approach in biblical interpretation.

Another very important determinant for a hermeneutic of congruent biblical theology in the classic Reformed creeds is the acceptance of the "consent of the parts" in Scripture. Q/A 4 of the Westminster Larger Catechism reads, inter alia, as follows:

The Scriptures manifest themselves to be the Word of God, by their majesty (Hos. 8:12; 1 Cor. 2:6-7, 13; Ps. 119:18, 129) and purity (Ps. 12:6; 119:140), by the consent of all the parts (Acts $10: 43 ; 26: 22)$, and the scope of the whole, which is to give all glory to God (Rom. $3: 19 ; 27) \ldots$

Scripture is thus not an inconsistent compendium of independent narratives that take place in various periods and situations. Irrespective of historical and chronological differences in the dating of biblical texts and contrasting and even contradictory historical facts, there is still a "consent of the parts" pointing to a theological unity. This theological unity has been described by various Reformed scholars with different concepts, such as "heilsgeschicte" (salvation history), biblical theology, covenant history, and revelation history (see, for example, Cullman 1948:147; Barth 1961:136; Reuman 2005:833; Ciampa 2007:254). Barton (1997:152) contends that the canonical books of Scripture should be read as "chapters in a single work" and that the Old and New Testaments are congruent. Kelsey (2009:154ff) discusses the view of the wholeness of Scripture in depth and agrees with Barton but, with certain pre-conditions. He utilises the concept of "canonical holy Scripture" and concludes that Scripture contains a 
"canon-unifying narrative" (Kelsey 2009:477). Some scholars in the Reformed theological paradigm argue that the wholeness (theology, harmony, congruence, unity) of Scripture becomes clear in the overarching theme of the reign (kingdom) of God. Scripture reveals in different narratives, prophecies, wisdom expressions and cultic experiences God's reign and his intention to renew creation by way of redemption (Christology) and regeneration (Holy Spirit). The idea of the constant reign of God in communion with people constitutes, according to Vriezen (1966:146), the unity of the theology of the Old Testament. The reign of God is also the basic message of the New Testament (Van der Walt 1962:37). Within this overarching theme, various theological themes such as, among others, reconciliation, life, liberation, communion, love, and holiness can be discerned and outlined. This harmonious wholeness makes the study of biblical systematic theology possible. For this reason, I choose the concept of hermeneutic of congruent theology as an expression of what the hermeneutics of the classic Reformed tradition entails. This approach to scripture means that the part should always be understood within the framework of the whole, and the exegete should be extremely cautious to single out isolated parts of the text and to phrase them into doctrines or moral codes applicable to all times and situations. The congruent theology determines the validity of doctrines and moral norms.

The theological foundation for a hermeneutic of congruent biblical theology can be summarised in the following statements:

- Scripture is the written revelation of God and is a holy text.

- Scripture is inspired by the Spirit of God and is more than just a collection of ancient texts.

- Scripture came into being by a divine-human interaction and is authoritative for faith and life.

- Scripture originated within different linguistic and literary contexts and contains multiple literary genres.

- Scripture is theologically congruent, irrespective of chronological and historical differences and contradictions that may occur in the text.

- Scripture reveals the reality of the renewing reign of God and its implications for the renewal of his creation.

These fundamental beliefs constitute the pre-conditions for a hermeneutic of congruent biblical theology and flow into a certain hermeneutical approach which will be outlined in the next section.

\section{Guiding principles for interpretation in a hermeneutic of congruent biblical theology}

Six guiding principles can be formulated from the fundamental beliefs mentioned above. These guiding principles can guide a hermeneutic of congruent biblical theology. These are as follows:

\section{Dealing with the reality of pre-understanding}

Research does not take place in a void. Researchers are influenced by their presuppositions which on their part are paradigm driven. This is also the case with biblical 
interpretation. No reader approaches the Scripture without some form of preunderstanding (Vorverständnis). Spykman (1995:121) explains that the self is always involved in the process of interpretation. Exegetes can never escape themselves or turn themselves off. They all approach Scripture with a sense of anticipation. In studying Scripture, they all wear "glasses" of one kind or another. The "glasses" can be the influence of their cultural contexts, social positions, education, and other forming and influencing factors that determine the paradigm of the reader. The "glasses" can be belief systems, theology, and ideology. Osborne (2006:29) also emphasises the pertinent role of the reader's context because readers often wish to harmonise the text with their belief systems and see its meaning in light of their own respective preconceived theological systems. The theological and ecclesiastical tradition of the reader brings about a certain expectation of what the text may reveal. Osborne (2006:29) then continues to say: "The problem is that our pre-understanding too easily becomes prejudice, a set of a priories that place a grid over Scripture and make it conform to these preconceived conceptions." The claim of a hermeneutic of congruent theology, that Scripture is the written Word of God and that it is organically inspired by the Spirit, is itself a pre-supposition that drives certain forms of pre-understanding in the process of interpretation of Scripture.

The question arises: Suppose that readers of the biblical text do their readings from the premise of their respective pre-suppositions, would it then not be a foregone conclusion that they are all left in a hopeless sea of subjectivity? This will indeed be the case if interpreters do not recognise their pre-understandings and deal with them. Subjectivity can be dealt with as long as the interpreters acknowledge and deal with preunderstanding by using the tools of the hermeneutical circle which entails the confirmation of pre-suppositions and the willingness to challenge them (see Osborne 2006:407; Grondin 2017:299-305). Therefore, readers of Scripture should be aware that their understanding of the text is influenced by a pre-understanding because of their respective paradigms, and they ought to deal with this reality. In this respect, three steps are important in the process of interpretation. Firstly, readers can acknowledge the existence of their pre-understanding, identify their pre-suppositions and affirm them in the process of deeper understanding. Secondly, as Gadamer (1975:258ff) proposes, interpreters can, from the angle of their respective contexts and pre-understandings, ask questions of the text. In this way, the thought world of the text opens itself up, and the dialogue that follows, reshapes the questions of the interpreter. A "fusion of horizons" (the horizon of the reader and the horizon of the text) emerges and flows into a valid interpretation. Thirdly, the findings of other readings driven by the pre-suppositions of other paradigms could be perused and compared with one's own, because biblical interpretation is a collective and ecumenical endeavour, as we are reminded by the apostle Paul in Eph. 3:16-19. ${ }^{8}$ Furthermore, the universal basis of language brings readers closer to each other. Other interpretations of readers driven by other paradigms, but dealing with the same text, can become a corrective of our own reading and interpretation, and in this way the influence of pre-understanding can be managed. In

I pray that out of his glorious riches he may strengthen you with power through his Spirit in your inner being, ${ }^{17}$ so that Christ may dwell in your hearts through faith. And I pray that you, being rooted and established in love, ${ }^{18}$ may have power, together with all the Lord's holy people, to grasp how wide and long and high and deep is the love of Christ, ${ }^{19}$ and to know this love that surpasses knowledge - that you may be filled to the measure of all the fullness of God. 
sum, the tools of the hermeneutical circle should be utilised in dealing with preunderstanding. These are as follows: affirm the pre-understanding, do the reading, compare the interpretation with other paradigm-driven interpretations and then revisit, and if necessary, rectify the determinants of the own pre-understanding.

\section{Dealing with the literary genres in the biblical text}

The revelation of God in the written word was written down not only by several authors but also in different several genres. He spoke to people in historical narratives, by way of people's experiences in the psalms and expressions of truth and wisdom, by way of symbols and metaphors, in prophecies, and by way of the teachings of Jesus and the apostles. The text of Scripture consists thus of various literary genres. Each literary genre of the biblical text poses its own challenges to the reader. Narratives, wisdom literature, prophecies, epistles, and symbolic images and expressions require different tools of interpretation (Ricoeur 1981b: chapter 3). They may be studied with literary interest in their genres, the structure of their compositions, the devices and force of their rhetoric, and the way in which they arrive at their respective answers (Kelsey 2009:135). Osborne (2006:181-343) proposes a comprehensive, thorough, and well-argued genre analysis and the implications of the various genres for their respective interpretations. To neglect the challenges posed by a genre can lead to erroneous interpretations and findings. For example, in the narrative genre, a description of a certain situation or cultural custom cannot be elevated to a prescription. Descriptions of the way of life of a patriarchal family and a polygamous marriage cannot be translated into an ethical principle condoning and advocating patriarchy and polygamy. Descriptions of capital punishments for various transgressions in ancient Israel cannot be interpreted as being prescriptions for the biblical sanctioning of capital punishment. The deeper spiritual experience of an author should not be proposed as normative for spirituality today, and customs in families and other relationships in antiquity cannot be prescribed as examples for family life and relationships today. Turning descriptions into prescriptions led to many questionable moral codes that influenced the moral life of Christians in the history of Reformed ethics, such as the inferiority of women, the defence of slavery, and the endorsement of violence as a way to solve problems and serve a good end. The reader ought to use the tools required by every genre to excavate the deeper meaning and message within the scope of the whole. In this respect, the acknowledgement of the congruence of biblical theology is important because it can serve as the tool for distinguishing between prescriptive and descriptive material in Scripture. For example, certain isolated parts of the biblical texts refer to the inferiority of women or the legitimacy of violence but, interpreted within the context of congruent theology, such conclusions will not be valid. To understand what the Bible teaches about the status of women or about human relations, the congruence of biblical theology must shed light on individual passages dealing with these issues in order to understand what is prescriptive and what is merely descriptive.

\section{Dealing with a grammatical analysis of the text within the context}

Gadamer (1975:258ff) reminds us that the connecting point of the authors of the biblical text and the readers of the text through the centuries is in the end the universal text. The universal text brings authors, readers, and Christian traditions in the same space, and the 
art of good and sound exegesis therefore remains the foundation of responsible theology. This article will not discuss the whole process of exegesis; it will discuss only the focal points flowing from a hermeneutic of congruent biblical theology. First, of all, the text under scrutiny can be established by way of the tools of the science of text-criticism and redaction criticism. Secondly, the grammatical structure has to be analysed within the historical context, and the meaning of the unit of thought in the text can be excavated by using the tools of lexicography (Van der Belt 2006:328). (For a thorough explanation of the other rules of exegesis see Peels 1996:52-92; Silva 1996:197-286; Osborne 2006:35180). Thirdly, the passage can be collated into what Kelsey (2009:458-477) epitomises as the "wholeness" of Scripture. The relation "part" and "whole" is fundamental in a hermeneutic of congruent biblical theology and will be briefly explained in the following paragraph.

\section{Dealing with the harmony of the text with the congruent theology of Scripture}

One of the principles of the reformed doctrine of Scripture mentioned above is that the revelation in Scripture is theologically congruent, irrespective of chronological and historical differences and contradictions that may occur in the text. This principle implies that grammatical analysis can be complemented by the theological interpretation of Scripture. Van der Kooi and Van den Brink (2012:554) indicate, with reference to various exponents of this idea, that this approach has again become a productive movement in the contemporary hermeneutical discourse. The "part" (passage in the biblical text) can thus be illumined by the "whole" (the congruent biblical theology). This principle has important implications for the process of interpretation. Firstly, the principle entails that Scripture can be regarded as its own interpreter (Scriptura Scripturae interpres) and enables the reader to approach difficult passages from the passages in which meaning is obvious. Secondly, the principle determines the necessity of the interpreter to distinguish between the centre of the revelation and the periphery. In dealing with Scripture, the reader ought to ask the following question: What are the essential teachings of Scripture that are a sine qua non for salvation, faith and life, and what are non-essentials (adiaphora) that are time bound or mere guidelines for a particular situation or a certain way of life. On the one hand, these directives protect the reader against a total secularisation of Scripture and, on the other hand, against "biblicism", which was defined earlier in this article. A hermeneutic of congruent biblical theology still holds these two directives in high esteem although they were sometimes neglected by some reformed traditions in South Africa when they resorted to forms of "biblicism". In this respect, one can refer to the defence of Apartheid theology, the exclusion of women for ordination in ecclesiastical offices and the forming of erroneous biblical-ethical norms for marriage, family, and sexuality. In all these cases, theological points of view, ecclesiastical practices and ethical norms were shaped on the foundation of certain passages taken out of the context of congruent theology and given a prescriptive status of their own.

\section{Dealing with the principle of Semper Reformanda}

One of the well-known sola's of the Reformed tradition is sola scriptura. This dictum typifies the centrality of Scripture as the inspired written Word of God and the only rule of faith and life in Reformed thinking. No human ideas (be they philosophy, ideology, 
papal claims, resolution of ecclesiastical councils or synods or creeds and confessions) can be equated with the authority of Scripture in this tradition. The Reformers, their contemporaries, and their followers through the ages proclaimed that Church, theology, worship, and Christian faith and life must adhere to the teachings of Scripture. To do this and keep on doing this, Scripture needs to be continually investigated with all the valid hermeneutical tools available for the reader. Closely related to this dictum is the saying in this tradition: ecclesia reformata semper reformanda (the reformed church must continue reforming). What does it mean for biblical interpretation today? Among other things, it means that the findings of exegesis are always provisional. Findings of biblical scholars can never be cast in stone. In a hermeneutic of congruent biblical theology, the idea of semper reformanda pictures the spirit in which readers should engage with the biblical text, encounter each other, and present their findings. This principle reminds us that understanding Scripture requires humility and the acknowledgement that all interpretation must always be revisited, reaffirmed and, if necessary, reformed. The same principle applies to all ecclesiastical resolutions which claim to be founded on Scripture. Therefore, Reformed Church Orders make provision for the revisiting of any resolution of major assemblies when such a resolution is deemed to be founded on an erroneous use or interpretation of Scripture.

\section{Conclusion}

The research question dealt with in this article reads as follows: can a hermeneutic of congruent biblical theology, founded in the classic reformed tradition, still be regarded as plausible and intelligible for doing theology and applying Christian ethics today? I venture to say, "yes", but on the following conditions:

- Scripture ought to be perceived as the written revelation (word) of God, inspired by the Spirit of God and as more than just a compilation of ancient texts.

- This inspiration can be termed "organic inspiration" because the Spirit inspired and used humans within their cultural and socio-historical contexts, spiritual experiences, language, and expectations to write the texts.

- Interpreters approach Scripture with various forms of pre-understanding, and they ought to deal with these by way of the tools of the hermeneutical circle.

- The deeper meaning of passages in Scripture come to light when they are interpreted in light of the wholeness of Scripture and its congruent biblical theology.

- A hermeneutic of congruent biblical theology can add value to biblical studies and new theological knowledge by taking into account findings in modern literary theories as long as they do not contravene the belief that Scripture is the inspired, authoritative written Word of God.

- A "hermeneutic of congruent biblical theology" must function within the realm of "semper rerformanda" - the continuous revisiting of past and current interpretation of Scripture. 


\section{BIBLIOGRAPHY}

Altizer, T.J.J. 1966. Theology and the death of God. In Altizer T.J.J. and Hamilton, W. (eds.), Radical theology and the death of God. New York The Bobbs Merrill Company, 1-15.

Barr, J. 2001. Fundamentalism. In Fahlbusch, E. et al. The encyclopaedia of Christianity, (vol. 2). Leiden: Brill, 363-365.

Barth, K. 1961. Church dogmatics (vol IV, pt 2): The doctrine of reconciliation. Edinburgh: T\&T Clark.

Barth, K. 1978. Church dogmatics (vol 1 and 2). Translated by G.T. Thomson and H Knight. Edinburgh: T\&T Clark.

Barton, J. 1997. Holy writings, sacred text; The canon in early Christianity. Louisville, Kentucky: Westminster John Knox Press.

Barton, J. 1998. Historical-critical approaches. In Barton, J. (ed.), The Cambridge companion in biblical interpretation. Cambridge: Cambridge University Press.

Bavinck, H. 1928. Gereformeerde dogmatiek (vol. 1). Kampen: Kok.

Beeke, J.R. and Ferguson, S.B. 1999. Reformed confessions harmonized with an annotated bibliography of Reformed doctrinal works. Grand Rapids, Michigan: Baker Books.

Berkouwer, C.C. and Van der Woude, A.S. 1969. De Bijbel in het geding: Een bundel beschouwingen over Scriftcritiek en Schriftgezag, Nijkerk: G.F. Callenbach.

Brunner, E. and Barth, K. 1946. Natural theology. London: Geoffrey Bles.

Bultmann, R. 1967. Jezus Christus en de mythe. Translated by L. de Liefde. Amsterdam: Ten Have.

Calvin, J. 2008 [1559]. Institutes of the Christian religion. Translated by H. Beveridge. Peabody, Massachusetts: Hendriksen.

Ciampa, R.E. 2007. The history of redemption. In Havemann, S.J. and House, P.R. Central themes in biblical theology: Mapping unity in diversity. Grand Rapids, Michigan: Baker Academic, 254-308.

Cox, H. 1965. The secular city, secularisation and urbanisation in theological perspective. London: Pelican Books.

Cullmann, O. 1948. Christus und die Zeit, Die uhrchristliche Zeit und Geschichtaufassung. Zürich: Evangeliscer Verlag.

Deist, F. 1994. Ervaring, rede en metode in Skrifuitleg: 'n Wetenskapshistoriese ondersoek na Skrifuitleg in die Ned. Geref. Kerk 1840-1990. Pretoria: Raad vir Geesteswetenskaplike Navorsing (Human Research Council).

Derrida, J. 1997. On grammatology. Translated by G.C. Spivak. Baltimore, MD: John Hopkins University Press.

Derrida, J. 2004. From outwork, prefacing in dissemination. In Drolet (ed.), The postmodern reader. London: Routledge, 147-153.

Douma, J. 1996. The Ten Commandments: Manual for the Christian life. Translated by Nelson. D Kloosterman. Phillipsburg, NJ: P \& R Publishing.

Fierro, A. 1977. The militant Gospel: an analysis of contemporary political theologies. London: S.C.M Press.

Foucault, M. 1970. The order of things. New York: Random House. 
Gadamer, H. 1975. Truth and method. Translated and edited by G. Brodin and J. Cumming, J. New York: Seabury.

Grondin, J. 2017. What is the hermeneutical circle? In Keane, N. and Lawn, C. (eds.), The Blackwell companion to hermeneutics. Oxford: Blackwell, 299-305.

Grabill, S.E. 2006. Rediscovering the natural law in Reformed theological ethics. Grand Rapids: Eerdmans, 66-80.

Hamilton, W. 1966. The death of God theologies today. In Altizer, T.J.J. and Hamilton, W. (eds.), Radical theology and the death of God. New York: The Bobbs Merrill Company.

Jasper, D. 1998. Literary readings of the Bible. In Barton, J. (ed.), The Cambridge companion in biblical interpretation. Cambridge: Cambridge University Press, 21-34.

Kärkkäinen, V.M. 2019. Christian theology in a pluralistic world: A global introduction. Grand Rapids, Michigan: Eerdmans.

Kelsey, D.H. 2009. Eccentric existence: A theological anthropology, (vol. 1). Louisville, Kentucky: Westminster John Knox Press.

Kuhn, T.S. 1970. The structure of scientific revolutions. Chicago: University of Chicago Press.

Lyotard. J-F. 1991. The post-modern condition: a report on knowledge. Translated by Geoff Bennington and Brian Massumi. Manchester: Manchester University Press.

Marsden, G.M. 1991. Understanding fundamentalism and evangelicalism. Grand Rapids: Eerdmans.

Osborne, G.R. 2006. The hermeneutical spiral: A comprehensive introduction to Biblical interpretation. Downers grove, IL: IVP Academic.

Peels, H.G.L. 1996. Het Woord is leven - over de Heilige Schrift. In Van den Brink, G., Van Campen, M. and Van den Graaf, J. (eds.), Gegrond geloof, kernpunten uit de geloofsleer in bijbels, historisch en belijdend perspectief. Zoetermeer: Uitgeverij Boekencentrum, 52-92.

Reuman, J. 2005. Salvation history. Fahlbusch, E. et al. The encyclopaedia of Christianity (vol. 4). Leiden: Brill, 832-836.

Ricoeur, P. 1981a. Hermeneutics and the human sciences. Edited and translated by J.B. Thompson. Cambridge: Cambridge University Press.

Ricoeur, P. 1981b. Essays on Biblical interpretation. Edited and translated by L.S. Mudge. London: SPCK.

Ritschl, D. 1999. Biblicism. In Fahlbusch, E. et al. The encyclopaedia of Christianity (vol. 1). Leiden: Brill, 255-256.

Silva, M. 1996. God, language, and Scripture. In Long, V.P., Longman, T., Muller, R.A., Poytress, V.S. and Silva, M. (eds.), Foundations of contemporary interpretation, six volumes in one. Grand Rapids, MI: Zondervan, 197-286.

Spykman, G.J. 1995. Reformational theology: A new paradigm for doing dogmatics. Grand Rapids, MI: Eerdmans.

Tracy, D. 1994. Literary theory and return of the forms for naming and thinking of God in theology. Journal of religion, 74(1994):302.

Thiselton, A.C. 2009. Hermeneutics: An introduction. Grand Rapids, MI: Eerdmans.

Vahanian, G. 1961. The death of God: The culture of our post-Christian era. New York: George Braziller. 
Van der Belt, H. 2006. Autopistia, the self-convincing authority of scripture in Reformed theology. Amsterdam: De Gereformeerde Bond in de Protestantse Kerk.

Van der Kooi, C. and Van den Brink, G. 2012. Christian dogmatics: An introduction. Translated by R. Bruinsma and J.D. Bratt. Grand Rapids, MI: Eerdmans.

Van der Walt, T. 1962. Die Koninkryk van God-naby! Kampen: Kok.

Van der Westhuizen, H. 2017a. The Word and the Spirit - Michael Welker's theological hermeneutics, (part 2). Stellenbosch Theological journal. Online: http://dx.doi.org/10.17570/stj.2017.v3nl.a20 (Accessed: 25 Jan 2020).

VanDrunen, D. 2010. Natural law and the two kingdoms: A study in the development of Reformed social thought. Grand Rapids: Eerdmans.

VanDrunen, D. 2014. Divine covenants and moral order: A biblical theology of natural law. Grand Rapids: Eerdmans.

Vriezen, T.C. 1966. Hoofdlijnen der Theologie van het Oude Testament. Wageningen: Veeneman and Zonen.

Welker, M. 1994. Gottes Geist. Theologie des Heiligen Geistes, Neukirchen-Vluyn: Neukirchener.

Welker, M. 1996. Geist und Wort - Wort und Geist. Concilium, 1996(3):159-165.

Witte, J. 2007. The reformation of rights: Law, religion, and human rights in early modern Calvinism. Cambridge: Cambridge University Press. 